\title{
Total synthesis of pyrrolo[2,3-c]quinoline alkaloid: trigonoine $B$
}

\author{
Takashi Nishiyama $^{1}$, Erina Hamada ${ }^{1}$, Daishi Ishii ${ }^{1}$, Yuuto Kihara ${ }^{1}$, Nanase Choshi ${ }^{1}$, \\ Natsumi Nakanishi ${ }^{1}$, Mari Murakami ${ }^{1}$, Kimiko Taninaka ${ }^{1}$, Noriyuki Hatae ${ }^{2}$ \\ and Tominari Choshi ${ }^{* 1}$
}

\section{Full Research Paper}

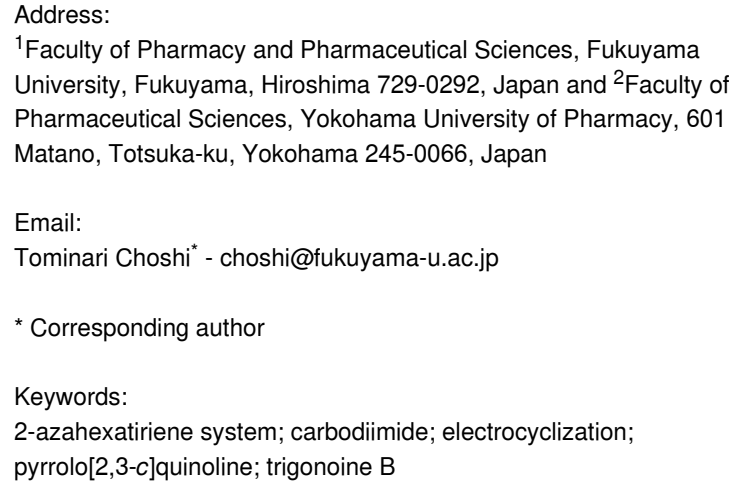

\author{
Beilstein J. Org. Chem. 2021, 17, 730-736. \\ https://doi.org/10.3762/bjoc.17.62 \\ Received: 26 January 2021 \\ Accepted: 05 March 2021 \\ Published: 16 March 2021 \\ Associate Editor: J. S. Dickschat \\ (C) 2021 Nishiyama et al.; licensee Beilstein-Institut. \\ License and terms: see end of document.
}

\begin{abstract}
The first total synthesis of the pyrrolo[2,3-c]quinoline alkaloid trigonoine B (1) was accomplished via a six-step sequence involving the construction of an $\mathrm{N}$-substituted 4-aminopyrrolo[2,3-c]quinoline framework via electrocyclization of 2-(pyrrol-3-yl)benzene containing a carbodiimide moiety as a 2-azahexatriene system. The employed six-step sequence afforded trigonoine B (1) in 9.2\% overall yield. The described route could be employed for the preparation of various $N$-substituted 4-aminopyrroloquinolines with various biological activities.
\end{abstract}

\section{Introduction}

In 2011, two novel alkaloids, namely trigonoine A and B, were isolated from the leaves of Trigonostemon lii by Hao and co-workers [1]. The structures of the compounds were elucidated through 1D and 2D NMR spectroscopy. It was determined that trigonoine $\mathrm{A}$ was a $\beta$-carboline alkaloid containing a 2,8 diazabicyclo[3.3.1]nonane ring system, while trigonoine B (1) was formed by a combination of 2,3-dihydroquinolin-4-one and $3 H$-pyrrolo[2,3-c]quinoline rearranged from a $\beta$-carboline skeleton (Figure 1).

Additionally, the antihepatitis B virus (HBV) activity of the alkaloids was evaluated in vitro using an HBV-transfected
HepG2 cell line. The antihuman immunodeficiency virus (HIV) properties were also investigated to determine whether trigonoine $\mathrm{A}$ and $\mathrm{B}$ could prevent the cytopathic effects of HIV-1 IIIB in C8166 cells. Notably, it was found that both natural products exhibited anti-HIV activity.

In addition to trigonoine B, aplidiopsamine A (2) [2] and marinoquinolines 3 [3] are natural products that possess the pyrrolo[2,3-c]quinoline skeleton (Figure 1). These pyrrolo[2,3$c$ ]quinolines have been demonstrated to show antimalarial and antibacterial biological activities [2-4]. Thus, the development of a convenient and efficient synthetic route to the pyrrolo[2,3- 
<smiles>COc1ccc2c(c1)nc(N1CCC(=O)c3ccccc31)c1[nH]ccc12</smiles><smiles>Nc1ncnc2c1ncn2Cc1nc2ccccc2c2cc[nH]c12</smiles>

1: trigonoine $B$

2: aplidiopsamine A<smiles>[R]c1nc2ccccc2c2cc[nH]c12</smiles>

3a: marinoquinoline $A(R=M e)$

3b: marinoquinoline $B(R=i B u)$

3c: marinoquinoline $C(R=$ benzyl)

3d: marinoquinoline $D(R=4$-hydroxybenzyl)

3e: marinoquinoline $E(R=$ indol-3-yl)

3f: marinoquinoline $F(R=$ indol-3-ylcarbonyl)

Figure 1: Natural products possessing the pyrrolo[2,3-c]quinoline skeleton.

c]quinoline skeleton has attracted considerable attention from organic and medicinal chemists. The total syntheses of aplidiopsamine A (2) [5-9] and marinoquinolines 3 [10-13] have been achieved by various synthetic strategies. Nevertheless, the total synthesis of trigonoine B (1) has not yet been reported.

We have been interested in the synthesis of heterocyclic compounds by constructing fused pyridine ring systems based on a thermal electrocyclization of an azahexatriene moiety [14,15]. It has been hoped that the development of compounds with enhanced biological activity would be possible using these natural products and their derivatives [16-18]. We have previously reported the total syntheses of indolo[3,2-c]quinoline (isocryptolepine) [19], azaanthracenones (kalasinamide, marcanine A and geovanine) [20], imidazo[4',5':4,5]pyrido[2,3- $b$ ]indole (grossularine-1 and -2) [21,22], imidazo[4,5-b]pyridine (2-amino-1-methyl-6-phenylimidazo[4,5-b]pyridine and 2-amino-1,6-dimethylimidazo[4,5-b]pyridine) [23], and imidazo[4,5-c]quinoline (imiquimod) [24] based on the electrocyclization of 2-azahexatriene involving an isocyanate moiety as the key intermediate.

In addition, we recently reported the total syntheses of marinoquinolines A (3a), B (3b), and E (3e) comprising the pyrrolo[2,3-c] quinoline skeleton [25]. As demonstrated in Scheme 1, Curtius rearrangement of carboxylic acid 4 resulted in the formation of isocyanate $\mathbf{5}$, which, upon electrocyclization furnished pyrrolo[2,3-c]quinoline $\mathbf{6}$. Intermediate $\mathbf{6}$ was subsequently transformed into triflate 7 , and the total syntheses of marinoquinolines $\mathbf{3 a}, \mathbf{3 b}$, and $\mathbf{3 e}$ were accomplished by introducing different substituents at the $\mathrm{C} 4$ position. However, despite our efforts to introduce dihydroquinoline derivatives into triflate $\mathbf{7}$ using various conditions, the synthesis of $\mathbf{8}$ could not be achieved. Consequently, we decided to develop a new synthetic strategy for the preparation of trigonoine B (1).

previous work<smiles>O=C(O)c1ccccc1-c1cc[nH]c1</smiles>

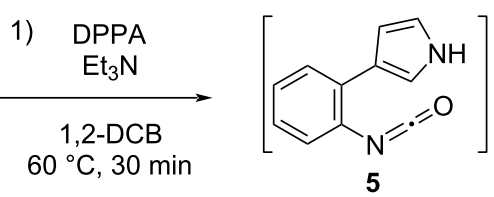

2)

$\Delta$ $120^{\circ} \mathrm{C}, 30 \mathrm{~min}$<smiles>O=c1[nH]c2ccccc2c2cc[nH]c12</smiles>
$\underset{\mathrm{rt}, 30 \mathrm{~min}}{\stackrel{\mathrm{Tf}_{2} \mathrm{O}, \mathrm{Py}}{\mathrm{CH}_{2} \mathrm{Cl}_{2}}}$<smiles>[Te]c1nc2ccccc2c2cc[nH]c12</smiles>

7<smiles>[R]c1nc2ccccc2c2cc[nH]c12</smiles>

3a: marinoquinoline $A(R=M e)$

3b: marinoquinoline $B(R=i B u)$

3e: marinoquinoline $E(R=$ indol-3-yl)

introduction of tetrahydroquinoloine moiety by direct amination

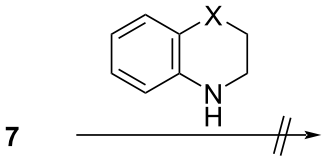<smiles>[X]c1ccccc1N(CCC)c1nc2ccccc2c2cc[nH]c12</smiles>

8a: $X=\mathrm{CH}_{2}$

8b: $X=\mathrm{C}=\mathrm{O}$
Scheme 1: Total synthesis of marinoquinolines and the failure of the introduction of a tetrahydroquinoline moiety by direct amination to triflate 7 .

Carbodiimides are valuable synthetic intermediates that can be obtained by an aza-Wittig reaction of isocyanates with iminophosphoranes or by dehydration of urea [26]. Molina et al. previously reported the synthesis of 2-aminopyridine derivatives through an electrocyclization of conjugated carbodiimides derived from an aza-Wittig reaction of iminophosphoranes and isocyanates [27]. Hibino and co-workers also achieved the preparation of mutagenic amino- $\alpha$-carbolines (2-amino- $9 \mathrm{H}$ pyrido[2,3- $b$ ]indole, $\mathrm{A} \alpha \mathrm{C}$ ) and $\mathrm{MeA} \alpha \mathrm{C}$ by the electrocyclization of 3-alkenyl-2-carbodiimidoindole derivatives obtained by an aza-Wittig reaction of indol-2-yl-iminophosphoranes and isocyanates [28].

In this work, we report the first total synthesis of trigonoine B (1) involving the construction of a pyrrolo[2,3-c]quinoline framework by electrocyclization of 2-(pyrrol-3-yl)benzene containing a carbodiimide moiety as a 2-azahexatriene system. 


\section{Results and Discussion}

Scheme 2 illustrates the retrosynthetic strategy designed to synthesize triogonoine B (1). It was speculated that the dihydroquinoline moiety of trigonoine B (1) could be constructed through a cycloamination reaction between positions $\mathrm{C} 1 \mathrm{a}$ and N1. The synthesis of the precursor pyrroloquinoline 9 possessing a substituted amino group at the 4-position could be achieved by the electrocyclization of pyrrol-3-ylbenzene $\mathbf{1 0}$ containing a carbodiimide moiety as a 2-azahexatriene system. Lastly, it was proposed that the carbodiimide $\mathbf{1 0}$ could be derived from urea $\mathbf{1 1}$

Therefore, we investigated the electrocyclization of a pyrrol-3ylbenzene containing a carbodiimide moiety. First, 2-(pyrrol-3yl)aniline 14 was synthesized by a Suzuki-Miyaura coupling reaction of 2-iodoaniline (12) and 3-(4,4,5,5-tetramethyl-1,3,2dioxaborolan-2-yl)-1-[tris(1-methylethyl)silyl]-1H-pyrrole (13) according to Pratt's conditions (Scheme 3) [29]. Subsequently, to remove the triisopropylsilyl (TIPS) protecting group, compound $\mathbf{1 4}$ was treated with tetra- $n$-butylammonium fluoride (TBAF) in THF, affording aniline $\mathbf{1 5}$ in $65 \%$ yield. Treatment of 15 with phenyl isocyanate in $\mathrm{CH}_{2} \mathrm{Cl}_{2}$ gave urea 16a in 54\% yield. To obtain carbodiimide 17a, 16a was treated with carbon tetrabromide $\left(\mathrm{CBr}_{4}\right), \mathrm{PPh}_{3}$, and $\mathrm{Et}_{3} \mathrm{~N}$ in $\mathrm{CH}_{2} \mathrm{Cl}_{2}$. The reaction was monitored by TLC, which confirmed the complete consumption of the starting material. However, after the workup, extraction, and removal of solvent (in vacuo), the appearance of the TLC plate changed due to the formation of various byproducts. Then, the reaction mixture was purified, but the desired carbodiimide 17a was not obtained, but amino- pyrroloquinoline 18 formed through electrocyclization of 17a in $25 \%$ yield. Notably, it was found that the electrocyclization of 17a proceeded easily at low temperature $\left(\approx 60{ }^{\circ} \mathrm{C}\right)$.

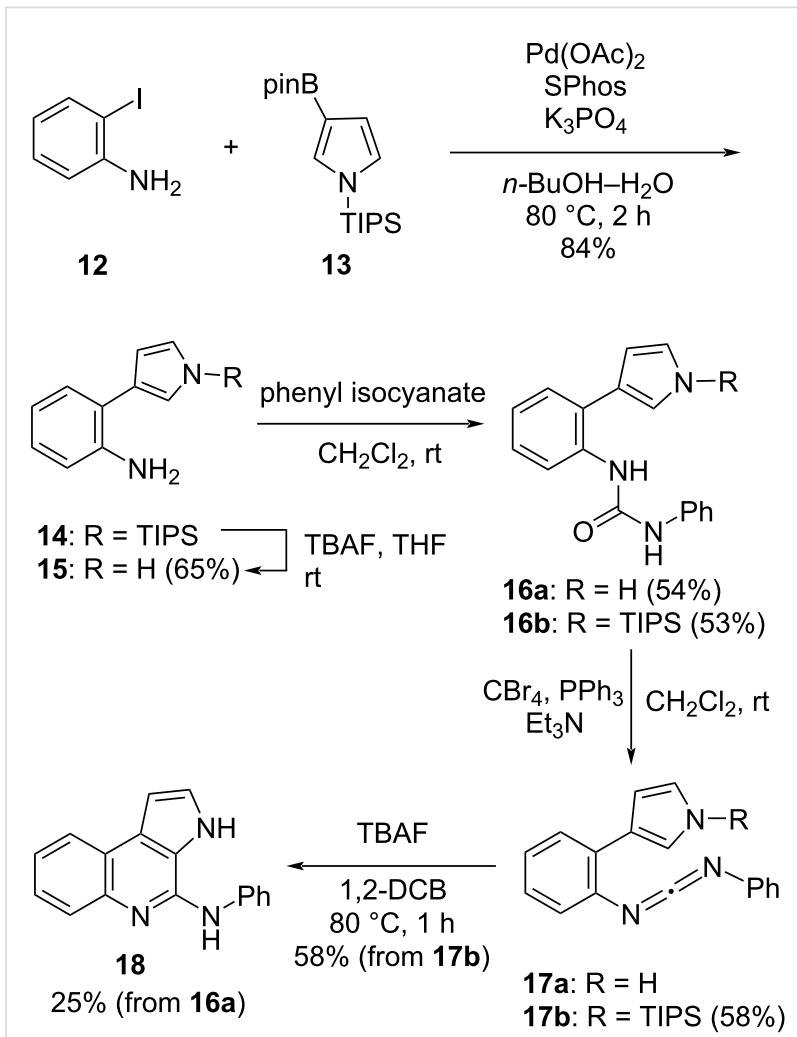

Scheme 3: Synthesis of $N$-substituted 4-aminopyrrolo[3,2-c]quinoline 18.<smiles>COc1ccc2c(c1)nc([N+]1=CCC(=O)c3ccccc31)c1[nH]ccc12</smiles><smiles>C=C=CCC(=O)c1ccccc1Br</smiles><smiles></smiles><smiles>[CH]=C</smiles><smiles>COc1ccc(-c2cc[nH]c2)c(N=C=NCCC(=O)c2ccccc2Br)c1</smiles> 
Although we tried to optimize the reaction conditions to improve the yield of $\mathbf{1 8}$, the yield could not be improved owing to the generation of numerous byproducts in the reaction of 16 a with $\mathrm{CBr}_{4}, \mathrm{PPh}_{3}$, and $\mathrm{Et}_{3} \mathrm{~N}$. Using the same procedure, carbodiimide $\mathbf{1 7 b}$ was then synthesized in $58 \%$ yield starting from aniline 14 via urea $\mathbf{1 6 b}$. Then, the electrocyclization of $\mathbf{1 7} \mathbf{b}$ was attempted, but the cyclization did not proceed at all. As possible reason we considered a steric hindrance of the TIPS group. Based on the above results, it was speculated that the electrocyclization of $\mathbf{1 7} \mathbf{b}$ could proceed continuously following the removal of the TIPS group. Indeed, when $\mathbf{1 7 b}$ was heated with TBAF in 1,2dichlorobenzene $(1,2-\mathrm{DCB})$ at $80{ }^{\circ} \mathrm{C}$, the expected reaction proceeded and the desired pyrroloquinoline $\mathbf{1 8}$ was obtained in $58 \%$ yield.
We subsequently examined the versatility of the electrocyclization of carbodiimides 20a-d as 2-azahexatriene systems (Table 1). First, urea derivatives 19a-d were synthesized by reacting 2-(pyrrol-3-yl)aniline $\mathbf{1 4}$ with isocyanates, which were commercially available or prepared from an appropriate carboxylic acid through a Curtius rearrangement reaction (50-98\% yield). Treatment of urea derivatives 19a-d with $\mathrm{CBr}_{4}, \mathrm{PPh}_{3}$, and $\mathrm{Et}_{3} \mathrm{~N}$ afforded carbodiimides $\mathbf{2 0 a}-\mathbf{d}$ in $64-75 \%$ yield. Compounds 21a-d were obtained in situ following the removal of the TIPS protecting group in 20a-d by TBAF in 1,2-DCB at $80^{\circ} \mathrm{C}$. The electrocyclization then proceeded immediately, affording the desired pyrroloquinolines 22a-c in $49-90 \%$ yield (Table 1, entries 1-3). However, the cyclization of 20d only gave a mixture of unidentified products (Table 1, entry 4).

Table 1: Synthesis of $N$-substituted 4-aminopyrrolo[3,2-c]quinolines 22 by electrocyclization of carbodiimides 20.<smiles>[R]NC(=O)Nc1ccccc1-c1ccn(C(C)C)c1</smiles>

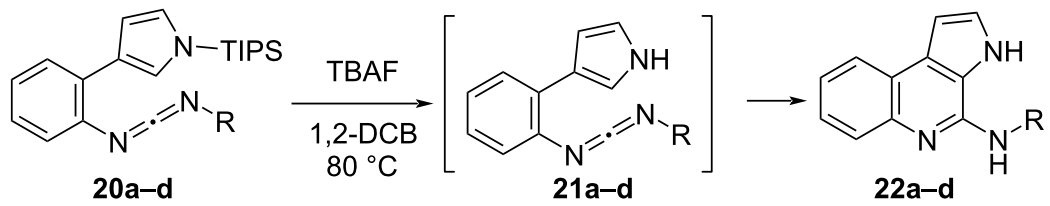

\begin{tabular}{|c|c|c|c|c|c|c|c|c|}
\hline \multirow[t]{2}{*}{ entry } & \multirow[t]{2}{*}{$\mathrm{R}$} & & \multicolumn{2}{|c|}{19} & \multicolumn{2}{|c|}{20} & \multicolumn{2}{|c|}{22} \\
\hline & & & $\begin{array}{c}\text { time } \\
\text { (h) }\end{array}$ & $\begin{array}{c}\text { yield } \\
(\%)\end{array}$ & $\begin{array}{c}\text { time } \\
\text { (h) }\end{array}$ & $\begin{array}{c}\text { yield } \\
(\%)\end{array}$ & $\begin{array}{c}\text { time } \\
\text { (h) }\end{array}$ & $\begin{array}{c}\text { yield } \\
(\%)\end{array}$ \\
\hline 1 & & $\mathbf{a}$ & 12 & 50 & 4 & 64 & 2 & 90 \\
\hline 2 & & b & 12 & 98 & 1 & $-^{a}$ & 2 & $49^{b}$ \\
\hline 3 & & c & 20 & 64 & 2 & 75 & 1 & 61 \\
\hline 4 & & d & 18 & 98 & 0.5 & 68 & 1 & $-^{c}$ \\
\hline
\end{tabular}

asince carbodiimide $\mathbf{2 0 b}$ was unstable, the next reaction was carried out without purification. bYield from $19 \mathrm{~b}$. 'Unknown compounds. 
Hence, we decided to evaluate the synthesis of the 2,3-dihydroquinolin-4-one moiety of trigonoine B (1) by cycloamination of 22c (Scheme 4). The Buchwald-Hartwig amination of 22c was conducted in the presence of $t$-BuONa, BINAP, and $\mathrm{Pd}_{2}(\mathrm{dba})_{3} \cdot \mathrm{CHCl}_{3}$; however, the desired tetrahydroquinoline $\mathbf{2 3}$ was not obtained and only 22c was recovered. We then examined the conditions reported by Orito and co-workers [30]. Gratifyingly, the treatment of $22 \mathrm{c}$ with $\mathrm{Pd}(\mathrm{OAc})_{2}, \mathrm{Cu}(\mathrm{OAc})_{2}$, and $\mathrm{K}_{2} \mathrm{CO}_{3}$ afforded the cyclized product 23 in $34 \%$ yield.

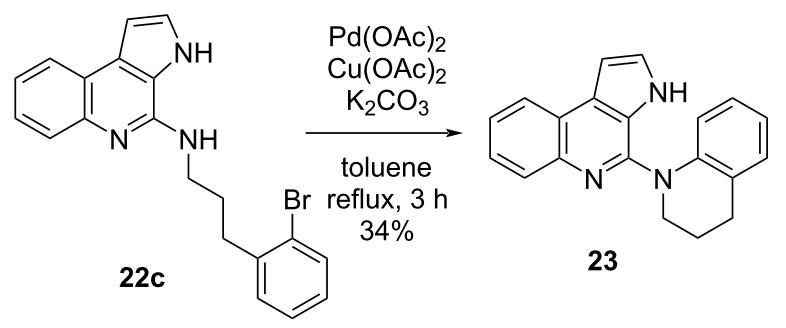

Scheme 4: Synthesis of the tetrahydroquinoline moiety through cycloamination.

The focus subsequently shifted to the total synthesis of trigonoine B (1) (Scheme 5). The key starting material, 2-iodo- 5-methoxyaniline (24), was synthesized according to the procedure previously reported by Wetzel and co-workers [31]. The Suzuki-Miyaura coupling of 2-iodoaniline derivative $\mathbf{2 4}$ and pyrrole-3-boronic acid pinacol ester $\mathbf{1 3}$ was carried out in the presence of $\mathrm{Pd}(\mathrm{OAc})_{2}$ and SPhos, followed by the treatment of the resulting 2-(pyrrol-3-yl)aniline 25 with 3-(2-bromophenyl)propyl isocyanate (26a), which afforded urea 27a in $60 \%$ yield. The treatment of urea 27a with $\mathrm{CBr}_{4}$ and $\mathrm{PPh}_{3}$ in the presence of $\mathrm{Et}_{3} \mathrm{~N}$ then gave carbodiimide 28a in a good yield of $74 \%$. Following the reaction of $\mathbf{2 8 a}$ with TBAF in 1,2-DCB and desilylation, the electrocyclization of 29a proceeded smoothly to afford the desired 4-aminopyrroloquinoline 30a in $68 \%$ yield. Subsequently, the cycloamination of $\mathbf{3 0 a}$ in the presence of $\mathrm{Pd}(\mathrm{OAc})_{2}, \mathrm{Cu}(\mathrm{OAc})_{2}$, and $\mathrm{K}_{2} \mathrm{CO}_{3}$ gave tetrahydroquinoline 31 in $25 \%$ yield. However, although attempts were made to optimize the cycloamination reaction conditions, the yield could not be improved. We hypothesized that the low yield could be attributed to a too low reactivity of the bromo group. Thus, the same reaction was performed using a compound bearing a more reactive iodo group.

Accordingly, 4-aminopyrroloquinoline 30b was synthesized from 2-(pyrrol-3-yl)aniline 25 and 3-(2-iodophenyl)propyl isocyanate (26b) in 3 steps using the same procedure as described<smiles>COc1ccc(I)c(N)c1</smiles>

24<smiles></smiles>

27a: $\mathrm{R}=\mathrm{Br}(60 \%)$

27b: $R=I(70 \%)$<smiles>[R]c1ccccc1N=Cc1c[nH]cc1-c1ccc(OC)cc1-c1ccncc1</smiles>

29a: $R=B r$ 29b: $R=1$

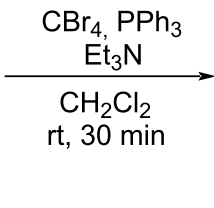

$\mathrm{CH}_{2} \mathrm{Cl}_{2}$ $30 \mathrm{~min}$<smiles>[R]c1ccccc1CNc1nc2cc(OC)ccc2c2cc[nH]c12</smiles>

30a: $R=\operatorname{Br}(68 \%)$ 30b: $R=I(82 \%)$

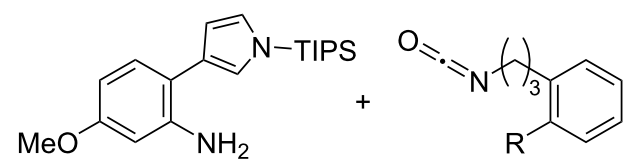

25

26a: $R=B r$

26b: $R=1$

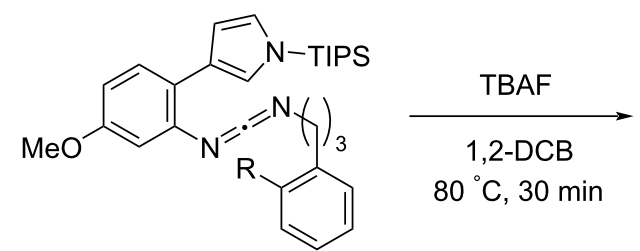

28a: $R=B r(74 \%)$

28b: $R=I(77 \%)$

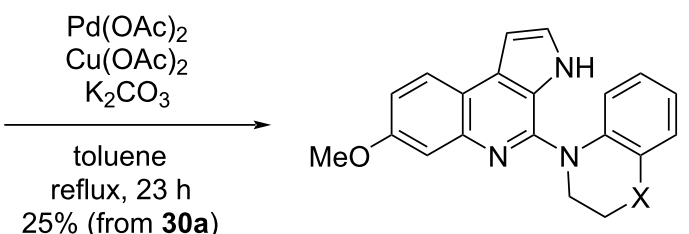

$25 \%$ (from 30a)

$73 \%$ (from 30b)

$\mathrm{KMnO}_{4}, \mathrm{MgSO}_{4}$

acetone- $\mathrm{H}_{2} \mathrm{O}$ rt, $36 \mathrm{~h}, 43 \%$

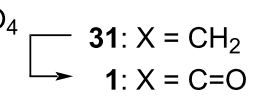


for 30a. The subsequent cycloamination of 30b gave tetrahydroquinoline $\mathbf{3 1}$ in $73 \%$ yield, thus resulting in a significantly improved yield.

Finally, the oxidation of tetrahydroquinoline $\mathbf{3 1}$ was examined. Following the evaluation of various reaction conditions [32-34], the best outcome was obtained upon treatment of $\mathbf{3 1}$ with $\mathrm{KMnO}_{4}$ and $\mathrm{MgSO}_{4}$ in an acetone- $\mathrm{H}_{2} \mathrm{O}$ solvent system [35]. Employing these conditions, trigonoine B (1) was obtained in $43 \%$ yield. The acquired physical and spectroscopic data of the herein synthesized compound $\mathbf{1}$ were consistent with those of the natural trigonoine B [1]. Thus, in this study, we successfully achieved the first total synthesis of trigonoine B (1).

\section{Conclusion}

The total synthesis of a pyrrolo[2,3-c]quinoline alkaloid, trigonoine B (1), was achieved for the first time through the electrocyclization of 2-(pyrrol-3-yl)benzene bearing a carbodiimide moiety as a 2 -azahexatriene system. The employed sixstep sequence afforded the desired product $\mathbf{1}$ in $9.2 \%$ overall yield. Notably, the developed synthetic route could be used for the synthesis of various $\mathrm{N}$-substituted 4-aminopyrroloquinolines. The investigation of the biological activity of trigonoine $\mathrm{B}$ and its derivatives is under evaluation.

\section{Supporting Information}

\section{Supporting Information File 1 \\ ${ }^{1} \mathrm{H}$ NMR and ${ }^{13} \mathrm{C}$ NMR spectra of all new compounds. [https://www.beilstein-journals.org/bjoc/content/ supplementary/1860-5397-17-62-S1.pdf]}

\section{ORCID ${ }^{\circledR}$ iDs}

Tominari Choshi - https://orcid.org/0000-0003-0233-8593

\section{Preprint}

A non-peer-reviewed version of this article has been previously published as a preprint: https://doi.org/10.3762/bxiv.2021.6.v1

\section{References}

1. Li, S.-F.; Di, Y.-T.; He, H.-P.; Zhang, Y.; Wang, Y.-H.; Yin, J.-L.; Tan, C.-J.; Li, S.-L.; Hao, X.-J. Tetrahedron Lett. 2011, 52, 3186-3188. doi:10.1016/j.tetlet.2011.03.015

2. Carroll, A. R.; Duffy, S.; Avery, V. M. J. Org. Chem. 2010, 75, 8291-8294. doi:10.1021/j0101695v

3. Sangnoi, Y.; Sakulkeo, O.; Yuenyongsawad, S.; Kanjana-opas, A.; Ingkaninan, K.; Plubrukarn, A.; Suwanborirux, K. Mar. Drugs 2008, 6, 578-586. doi:10.3390/md6040578

4. Okanya, P. W.; Mohr, K. I.; Gerth, K.; Jansen, R.; Müller, R. J. Nat. Prod. 2011, 74, 603-608. doi:10.1021/np100625a
5. Ni, L.; Li, Z.; Wu, F.; Xu, J.; Wu, X.; Kong, L.; Yao, H. Tetrahedron Lett. 2012, 53, 1271-1274. doi:10.1016/j.tetlet.2011.12.124

6. Schwalm, C. S.; Correia, C. R. D. Tetrahedron Lett. 2012, 53, 4836-4840. doi:10.1016/j.tetlet.2012.06.115

7. Ma, X.; Vo, Y.; Banwell, M. G.; Willis, A. C. Asian J. Org. Chem. 2012, 1, 160-165. doi:10.1002/ajoc.201200037

8. Lindsay, A. C.; Sperry, J. Synlett 2013, 24, 461-464. doi:10.1055/s-0032-1318137

9. Aguiar, A. C. C.; Panciera, M.; Simão dos Santos, E. F.; Singh, M. K.; Garcia, M. L.; de Souza, G. E.; Nakabashi, M.; Costa, J. L.; Garcia, C. R. S.; Oliva, G.; Correia, C. R. D.; Guido, R. V. C. J. Med. Chem. 2018, 61, 5547-5568. doi:10.1021/acs.jmedchem.8b00143

10. Mahajan, J. P.; Suryawanshi, Y. R.; Mhaske, S. B. Org. Lett. 2012, 14, 5804-5807. doi:10.1021/ol302676v

11. Yamaoka, Y.; Yoshida, T.; Shinozaki, M.; Yamada, K.-i.; Takasu, K. J. Org. Chem. 2015, 80, 957-964. doi:10.1021/j0502467m

12. Bolte, B.; Bryan, C. S.; Sharp, P. P.; Sayyahi, S.; Rihouey, C.; Kendrick, A.; Lan, P.; Banwell, M. G.; Jackson, C. J.; Fraser, N. J.; Willis, A. C.; Ward, J. S. J. Org. Chem. 2020, 85, 650-663. doi:10.1021/acs.joc.9b02725

13. Panarese, J. D.; Lindsley, C. W. Org. Lett. 2012, 14, 5808-5810. doi:10.1021/ol3024665

14. Choshi, T.; Hibino, S. Heterocycles 2011, 83, 1205-1239. doi:10.3987/rev-10-691

15. Hibino, S. Yakugaku Zasshi 2016, 136, 607-648. doi:10.1248/yakushi.15-00273 and related references cited

16. Furukawa, Y.; Sawamoto, A.; Yamaoka, M.; Nakaya, M.; Hieda, Y.; Choshi, T.; Hatae, N.; Okuyama, S.; Nakajima, M.; Hibino, S. Molecules 2019, 24, 1366. doi:10.3390/molecules24071366

17. Itoh, T.; Hatae, N.; Nishiyama, T.; Choshi, T.; Hibino, S.; Yoshimura, T.; Ishikura, M. Med. Chem. Res. 2018, 27, 412-419. doi:10.1007/s00044-017-2068-6

18. Nishiyama, T.; Hatae, N.; Mizutani, M.; Yoshimura, T.; Kitamura, T.; Miyano, M.; Fujii, M.; Satsuki, N.; Ishikura, M.; Hibino, S.; Choshi, T. Eur. J. Med. Chem. 2017, 136, 1-13. doi:10.1016/j.ejmech.2017.04.071

19. Hayashi, K.; Choshi, T.; Chikaraishi, K.; Oda, A.; Yoshinaga, R.; Hatae, N.; Ishikura, M.; Hibino, S. Tetrahedron 2012, 68, 4274-4279. doi:10.1016/j.tet.2012.03.055

20. Nishiyama, T.; Hatae, N.; Chikaraishi, K.; Uchida, K.; Yokoyama, C.; Hibino, S.; Choshi, T. Heterocycles 2019, 99, 415-424. doi:10.3987/com-18-s(f)36

21. Choshi, T.; Yamada, S.; Sugino, E.; Kuwada, T.; Hibino, S. J. Org. Chem. 1995, 60, 5899-5904. doi:10.1021/jo00123a028

22. Choshi, T.; Yamada, S.; Sugino, E.; Kuwada, T.; Hibino, S. Synlett 1995, 147-148. doi:10.1055/s-1995-4910

23. Choshi, T.; Tonari, A.; Yoshioka, H.; Harada, K.; Sugino, E.; Hibino, S. J. Org. Chem. 1993, 58, 7952-7954. doi:10.1021/jo00079a055

24. Yoshioka, H.; Matsuya, Y.; Choshi, T.; Sugino, E.; Hibino, S. Chem. Pharm. Bull. 1996, 44, 709-714. doi:10.1248/cpb.44.709

25. Nishiyama, T.; Murakami, M.; Taninaka, K.; Hamada, E.; Endo, M.; Kinou, D.; Hatae, N.; Choshi, T. Heterocycles 2021, in press. doi:10.3987/com-20-s(k)14

26. Tsukano, C.; Nakajima, M.; Hande, S. M.; Takemoto, Y. Org. Biomol. Chem. 2019, 17, 1731-1735. doi:10.1039/c8ob02224k 27. Molina, P.; Fresneda, P. M.; Alarcón, P. Tetrahedron Lett. 1988, 29 , 379-380. doi:10.1016/s0040-4039(00)80101-x 
28. Hibino, S.; Sugino, E.; Kuwada, T.; Ogura, N.; Shintani, Y.; Satoh, K. Chem. Pharm. Bull. 1991, 39, 79-80. doi:10.1248/cpb.39.79

29. Morrison, M. D.; Hanthorn, J. J.; Pratt, D. A. Org. Lett. 2009, 11, 1051-1054. doi:10.1021/ol8026957

30. Harada, R.; Nishida, N.; Uchiito, S.; Onozaki, Y.; Kurono, N.; Senboku, H.; Masao, T.; Ohkuma, T.; Orito, K. Eur. J. Org. Chem. 2012, 366-379. doi:10.1002/ejoc.201101214

31. Wetzel, A.; Gagosz, F. Angew. Chem., Int. Ed. 2011, 50, 7354-7358. doi:10.1002/anie.201102707

32. Nakanishi, M.; Bolm, C. Adv. Synth. Catal. 2007, 349, 861-864. doi:10.1002/adsc.200600553

33. Bonvin, Y.; Callens, E.; Larrosa, I.; Henderson, D. A.; Oldham, J.; Burton, A. J.; Barrett, A. G. M. Org. Lett. 2005, 7, 4549-4552. doi:10.1021/ol051765k

34. Wu, S.; Liu, C.; Luo, G.; Jin, Z.; Zheng, P.; Chi, Y. R. Angew. Chem., Int. Ed. 2019, 58, 18410-18413. doi:10.1002/anie.201909479

35. Silva, S. B. L.; Della Torre, A.; de Carvalho, J. E.; Ruiz, A. L. T. G.; Silva, L. F., Jr. Molecules 2015, 20, 1475-1494. doi:10.3390/molecules20011475

\section{License and Terms}

This is an Open Access article under the terms of the Creative Commons Attribution License (https://creativecommons.org/licenses/by/4.0). Please note that the reuse, redistribution and reproduction in particular requires that the author(s) and source are credited and that individual graphics may be subject to special legal provisions.

The license is subject to the Beilstein Journal of Organic Chemistry terms and conditions: (https://www.beilstein-journals.org/bjoc/terms)

The definitive version of this article is the electronic one which can be found at: https://doi.org/10.3762/bjoc.17.62 